\title{
The Implementation of Organizational Culture Based on Tri Hita Karana in the Effort to Realize the Organizational Performance in PDAM Buleleng Regency
}

\author{
Luh Kartika Ningsih ${ }^{*}$, Ni Luh Putu Eka Yudi Prastiwi², Ni Made Sri Ayuni ${ }^{3}$ \\ 1,2,3 Sekolah Tinggi Ilmu Ekonomi Satya Dharma Singaraja
}

\author{
A R T I C L E I N F O \\ Article history: \\ Received 19 February 2019 \\ Received in revised form \\ 16 March 2019 \\ Accepted 15 April 2019 \\ Available online 26 May \\ 2019 \\ Keywords: \\ Organizational Culture, \\ Total Quality Management, \\ Human Resource \\ Management, Employee \\ Performance, and \\ Organizational Performance
}

\begin{abstract}
A B S T RAC T
This study aims to determine the role of Organizational Culture based on Tri Hita Karana in the effort to realize Organizational Performance by taking into account other factors such as Human Resource Management, Total Quality Management, and Employee Performance. This study uses a quantitative approach. The data analysis technique used in this study is a structural equation model (SEM) based on variance or Component based SEM, known as Partial Least Square (PLS) Visual version 3.2.7. The number of samples used was 48 people with t-table values for significance levels $\alpha=0.05$ and degree of freedom (df) $=46$ is 2.58 . The results show that there are two relationships that show significant results, namely the role of Organizational Culture based on Tri Hita Karana on Employee Performance has a value of 17.353 with t-statistics > t-table $(17.353>$ 2.58). And the same results are also shown in the relationship between Total Quality Management and Organizational Performance with a value of $8.232>2.58$. Different results are shown in 4 other relationships, namely the influence of the organization's culture on organizational performance, the influence of HRM on organizational performance, the influence of HRM on employee performance, and the influence of total quality management on employee performance with t-statistics $<\mathrm{t}$ - table $(0.220<2.58),(0.544<2.58),(0.866<2.58)$, and $(0.553<2.58)$. From the results of this study it can be seen that there are still several factors that have not been able to provide a significant value on organizational performance in the PDAM Buleleng.
\end{abstract}

\footnotetext{
* Corresponding author.

E-mail addresses: luhkartikaningsih@gmail.com (Luh Kartika Ningsih)
} 


\section{Introduction}

Human Resource Performance (HR) is a term derived from the word 'job performance' or 'actual performance' (work performance or actual achievement achieved by someone). According to Mangkunegara (2002), performance is the result of work in quality and quantity achieved by an employee in carrying out his duties in accordance with the responsibilities given to him. Total Quality Management (TQM) is an approach in improving quality systematically by using many dimensions and has been widely applied by many companies with the aim of improving performance such as quality, productivity and profitability. Quality has become one of the important aspects in competition in the global market. Every company can improve its performance through continuous improvement in business activities focused on consumers, which includes the entire organization and emphasis on flexibility and quality. Therefore, the quality and management are always associated with continuous improvement activities to win the competition (Musran, 2010).

Organizational culture should be owned by companies including government agencies in order to have values, norms, references, guidelines that must be implemented. Organizational culture is also a unifying employee, reducing conflict and motivating employees to carry out tasks well, so that it has a positive effect on employee behavior and performance. A company or organization that has a strong culture will produce good performance in the long term, Yoga (2012). The concept of cosmology Tri Hita Karana is a tough philosophy of life. It is commonly understood that business activities in a company must be profit oriented. Thus, business analysis is generally activity oriented to minimize inputs, optimize output and maximize profits (Windia, 2011).

Likewise in the Regional Water Supply Company (PDAM) of Buleleng Regency, with the Implementation of the Company's Vision of making independent companies with excellent service based on the philosophy of Tri Hita Karana, Regional Water Companies (PDAM) of Buleleng Regency are not only profit oriented, but also pay attention environment in terms of social interests, which are always carried out in the anniversary of the PDAM Buleleng Regency. Palemahan activities are carried out by reforestation (forest replanting) near water sources with the aim of always maintaining natural harmony, especially preserving the forest as a buffer of water so that mutualism symbiosis will occur, namely mutual benefits, namely forest will be maintained and PDAM Buleleng can manage abundant springs as raw material in producing and distributing water to the community. From Pawongan, there are activities to provide assistance to nursing homes in the Buleleng Regency, such as the Mara Pati Jara Nursing Home in Lovina, the Punia Fund Orphanage in Banyuning and similar orphanages in Buleleng Regency, providing assistance to veterans in Buleleng Regency. Parhyangan activities are always offered regularly to various temples in Bali and outside Bali. Chen (2004) in his research through a survey of organizations found that organizational performance is influenced by organizational culture and leadership style.

The assessment results of the performance of PDAM Buleleng Regency for 2013 is 69.43 in the "good" category and the performance value for 2012 is 69.98 in the "good" category. Compared to 2012, the value of performance in 2013 decreased by 0.55 points with details as follows

Table 1. The Assessment Result of the Performance of PDAM Buleleng Regency (BPKP, 2015)

\begin{tabular}{|c|c|c|c|c|c|c|c|c|c|}
\hline \multirow{2}{*}{$\begin{array}{l}\boldsymbol{N} \\
\boldsymbol{o}\end{array}$} & \multirow{2}{*}{$\begin{array}{l}\text { Aspects of } \\
\text { Assessment }\end{array}$} & \multicolumn{2}{|c|}{2012} & \multicolumn{2}{|c|}{2013} & \multicolumn{2}{|c|}{2014} & \multicolumn{2}{|c|}{2015} \\
\hline & & Result & Value & Result & Value & Result & Value & Result & Value \\
\hline 1 & Financial Aspects & 46 & 34,50 & 43 & 32,25 & 43 & 32,25 & 49 & 36,75 \\
\hline 2 & Operational Aspects & 27 & 22,98 & 29 & 24,68 & 30 & 25,53 & 29 & 24,68 \\
\hline 3 & $\begin{array}{l}\text { Administrative } \\
\text { Aspects }\end{array}$ & 30 & 12,50 & 30 & 12,50 & 28 & 11,67 & 30 & 12,50 \\
\hline
\end{tabular}

The value of performance in the financial aspects has decreased by 2.25 points because the profit to productive ratio and profit to sales ratio in 2013 are lower than the 2012 ratio. The value of performance on operational aspects increased by 1.70 points which was influenced by the level of water loss from $20.93 \%$ in 2012 to $19.92 \%$ in 2013 (BPKP, 2015). In the table above, it can be seen that there was a decline in the value of operational aspects of 0.85 points compared to 2014 due to services experiencing a decrease of 0.85 points, from 25.53 in 2014 to 24.68 in 2015 due to the rate of increase in service provision 2015 was lower than in 2014 (BPKP, 2015).

Organizational culture is a basic assumption, values, beliefs, behaviors and shared attitudes adopted by the organization that are used as references in understanding the internal and external environment for the achievement of organizational goals (Bharadwaj, 1993). Sagiv (2007) emphasizes that there is a 
close relationship and interaction between community culture (i.e., external environment, institutions) and organizational culture (i.e., internal environment, self-reflection, self-reference, and identity). The philosophy of Tri Hita Karana as a cultural value of Balinese society consists of three words, namely, tri means three, hita means happiness, and karana means cause. So Tri Hita Karana can be interpreted as three causes of happiness. The application of organizational culture is inseparable from Balinese cultural values, namely the philosophy of Tri Hita Karana, which generally becomes the basic values of the culture of several organizations and companies in Bali (Dewi, 2007). This study uses indicators of the application of the culture of tri hita karana-based organizations in previous studies (Winata, 2015). The application of Tri Hita Karana values as an organizational culture applied by PDAM Buleleng district, in this study combined between the models developed by Schein (2010) on the three levels of organizational culture and dimensions of the Tri Hita Karana concept in Bali as follows Table 2.

Table 2. Organizational Culture of PDAM Based On The Values of Tri Hita Karana

\begin{tabular}{|c|c|c|c|}
\hline $\begin{array}{l}\text { Basic } \\
\text { Element }\end{array}$ & BasicUnderlyingAssumstion & Espoused Values & Artifacts \\
\hline Parhyangan & $\begin{array}{l}\text { The values that are already } \\
\text { exist in the PDAM are based } \\
\text { on the belief in God Almighty }\end{array}$ & $\begin{array}{l}\text { The philosophy, } \\
\text { objectives and strategies } \\
\text { of the PDAM are based } \\
\text { on the belief in God } \\
\text { Almighty }\end{array}$ & $\begin{array}{l}\text { PDAM operations and } \\
\text { production activities are } \\
\text { based on the belief in God } \\
\text { Almighty }\end{array}$ \\
\hline Pawongan & $\begin{array}{l}\text { The Harmonization of } \\
\text { relations between employees } \\
\text { and administrators through } \\
\text { the values and beliefs that } \\
\text { already exist in the PDAM }\end{array}$ & $\begin{array}{l}\text { The Harmony of relations } \\
\text { between employees and } \\
\text { administrators through } \\
\text { the strategy guidelines } \\
\text { and objectives of the } \\
\text { PDAM }\end{array}$ & $\begin{array}{l}\text { There is a clear structure } \\
\text { to support PDAM } \\
\text { operations }\end{array}$ \\
\hline Palemahan & $\begin{array}{l}\text { The existence of sacred } \\
\text { buildings as a form of respect } \\
\text { for the Almighty God }\end{array}$ & $\begin{array}{lr}\text { The strategy } & \text { and } \\
\text { objectives of the } & \text { PDAM } \\
\text { are directed } & \text { at } \\
\text { preserving } & \text { the } \\
\text { environment } & \end{array}$ & $\begin{array}{l}\text { The operational activities } \\
\text { of the PDAM apply the } \\
\text { concept of local } \\
\text { environmental } \\
\text { sustainability }\end{array}$ \\
\hline
\end{tabular}

Source: Winata (2015)

In this literature review, it also be explained some previous studies that became the theoretical basis in conducting research, namely:

Table 3. Theoretical Basis In Conducting Research,

$\begin{array}{lll}\text { Researcher } & \text { Research Title } & \text { Research Result }\end{array}$

Nel Arianty (2014) Effect of Organizational Culture on Employee Performance

Muhammad

Kurniawan (2013)

Effect of Organizational Commitment, Organizational Culture, and Job Satisfaction on the Performance of Public Organizations

Said Alhudri \& The Effect of Total Quality Meyzi Heriyanto Management (TQM) Implementation (2015)

Callystha Prayhoego Devie (2013) on Employee Performance at PT. PLN Persero Ranting Bangkinang

Analysis of the Effect of Total Quality dan Management on Competitive Advantage and Company Performance
Organizational Culture has a significant effect on Employee Performance

Organizational culture has a significant positive effect on the performance of public organizations

Total Quality Management (TQM) has a significant positive effect on Employee Performance

Total Quality Management (TQM) has a significant positive effect on Company Performance 


$\begin{array}{ll}\text { Fenina Ezra Wulan } & \text { The Effect of Human Resource } \\ \text { Kasenda } & \text { \& } \\ \text { Christoffel } & \text { Management Practices on Employee } \\ \text { Mintardjo } & \text { Performance at Manado State and } \\ & \text { Auction Service Office (KPKNL) }\end{array}$

Fauzi
Farchan HRM Strategy A Way to Create Organizational Performance Achieving Competitive Advantages
Career Planning, Job Performance Assessment, and Training in human resources have a significant effect on employee performance at KPKNL Manado

Strategic human resource management is a link that links between strategic roles and objectives that result in achieving business performance and developing organizational culture and fostering innovation and flexibility

Based on the description of several theories about the variables studied, the theoretical framework can be formulated as follows:

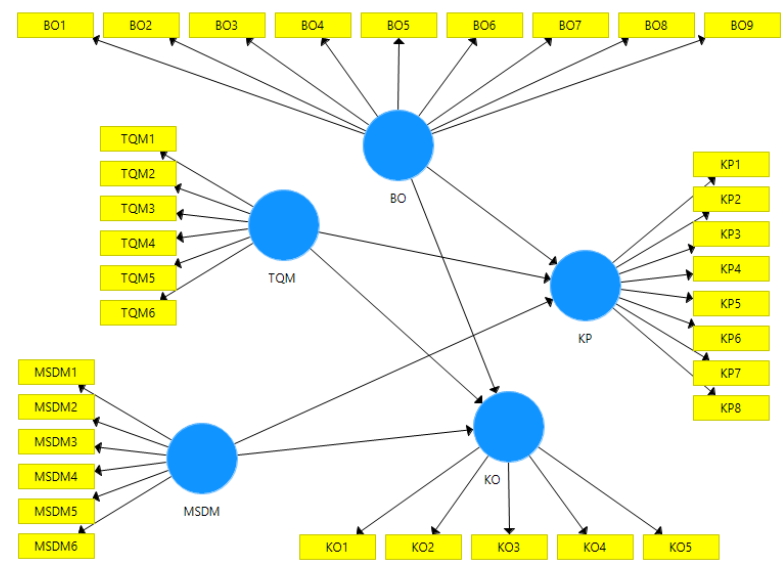

Figure 1. Theoretical Framework

\section{Methods}

The types of data used in this study include quantitative and qualitative data which can be explained as follows: Quantitative data, in this case the quantitative data needed are: Number of Employees, number of facilities and infrastructure, and results of questionnaires. Qualitative data is the main data source in qualitative research which is words and actions, the rest are additional data such as documents and other information that are obtained from PDAM Buleleng Regency such as the history of the establishment of PDAM Buleleng Regency, organizational structure, and explanation of each part in organization.

According to Arikunto (2010) said, "Population is the whole subject of research. If someone wants to examine all the elements in the research area, the research is a population." The population in this study is the Board of Directors, Head of SPI, Head of R \& D, Head of Division, Head of Sub-Division, Head of Subdivision, Chief of Office, Chief of Section and Head of the Unit in PDAM Buleleng Regency with a total population of 48 people. Sugiyono (2012) said, Samples are part of the number of characteristics possessed by the population. Namely the total population of 48 people from the Regional Water Supply Company (PDAM) of Buleleng Regency was made as a sample.

The analysis technique used in this study is a variance-based structural equation (Structural Equation Modeling-SEM) or Component based SEM, which is known as the Visual version 1.04bl Partial Least Square (PLS). PLS-SEM aims to test predictive relationships between constructs by looking at whether there is a relationship or influence between the constructs 


\section{Result and Discussion}

Validity and Reliability of Outer Model

In the outer model of validity test there are two factors that will be observed in the validity test, namely the score of loading factor (convergent validity) and the score of cross loading (discriminant validity). Convergent validity measures the correlation between items with constructs in the study. Individual reflexive measures are said to correlate if more than 0.7 with the construct which want to measure. However, for the initial stage of research on the development of a scale measuring the score of a loading factor of 0.6 it was considered sufficient (Ghozali, 2008). In the initial stage, data testing was carried out to determine the accuracy of indicators in explaining exogenous constructs on the model using factor loading. Based on the path diagram the following research model shows the results as in Figure 02

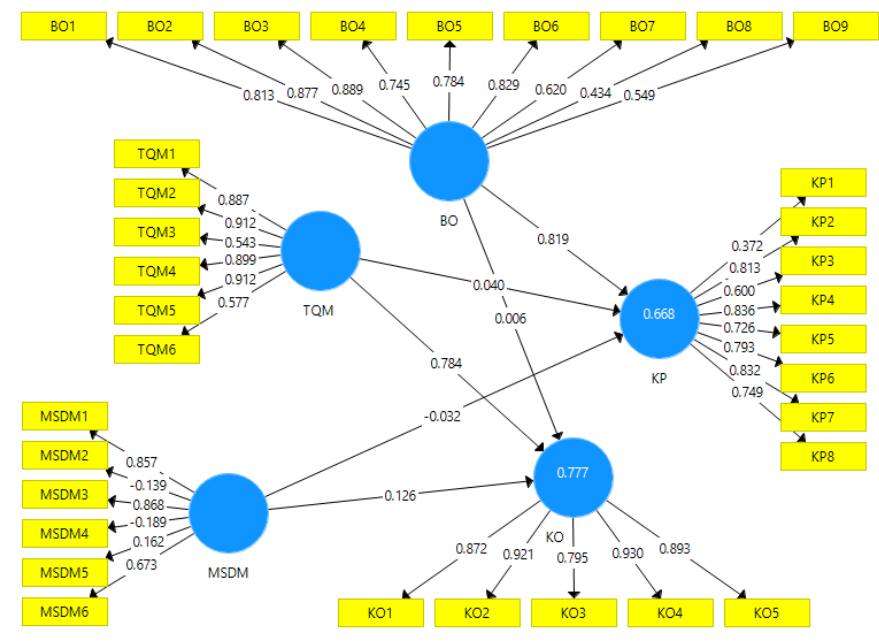

Figure 2. The score of Loading Factor before estimation using the PLS Path Diagram

Based on the picture above, there were several indicators which score of loading factor $<0.6$, namely: B08, B09, TQM3, MSDM2, MSDM4, MSDM5, and KP1. The indicator must be removed from the model and re-estimation carried out. After repeating estimation by issuing the indicator that has a score of loading factor $<0.6$, re-estimation results of path diagrams can be seen in figure 03 below:

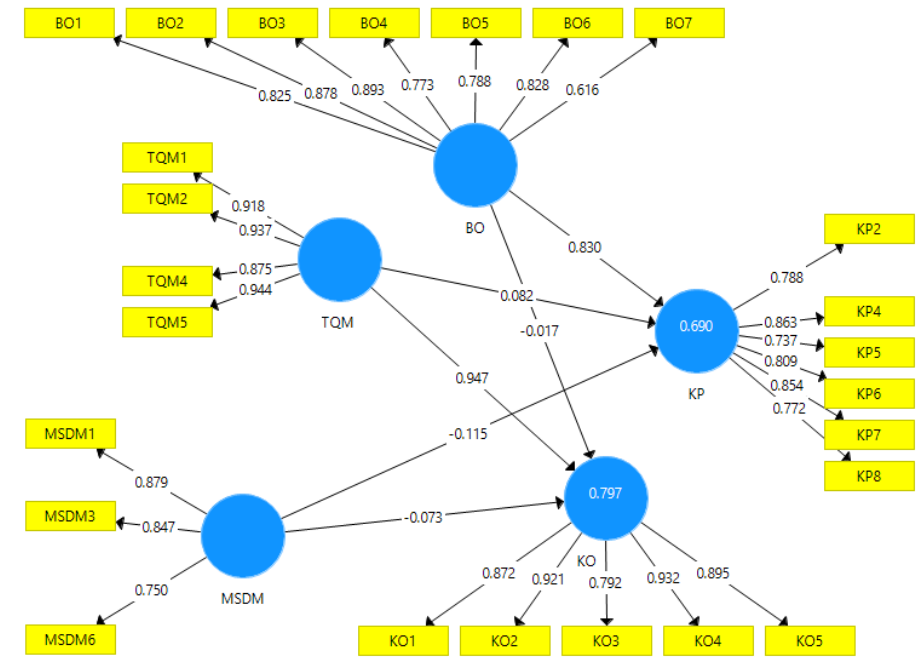

Figure 3. The Score of Loading Factor after estimation using the PLS Path Diagram

Based on the picture above, the score of loading factors after re-estimation, the results have met convergent validity because all loading factors were $>0.6$. Thus, it can be concluded that the convergent validity of all constructs was valid. 
Reliability can be seen from the Composite Reliability (CR) and Average Variance Extract (AVE) values. Composite Reliability was said to be good if it has a value of $\geq 0.7$. And the score of Average Variance Extract (AVE) was said to be good if it has a score of $\geq 0.5$ (Ghazali, 2009). The data from AVE and CR test results were shown in Table 4 below:

Table 4. The Score of Reliability

\begin{tabular}{cccc}
\hline Variable & Average Variance Extract (AVE) $\geq 0,5$ & Composite Reliability $(\mathrm{CR}) \geq 0,7$ & Conclusion \\
\hline BO & 0,648 & 0,927 & Good Reliability \\
MSDM & 0,684 & 0,866 & Good Reliability \\
TQM & 0,844 & 0,956 & Good Reliability \\
KP & 0,648 & 0,917 & Good Reliability \\
KO & 0,781 & 0,947 & Good Reliability \\
\hline
\end{tabular}

Based on the results of the validity and reliability test of the measurement model, it can be concluded that all observed variables valid measuring the latent variables. And the reliability of the measurement model shows good results. This shows that indicators are reliable in compiling exogenous constructs.

Evaluation of the second type of structural model was the relationship between exogenous constructs by observing the value of R2 generated through data processing. R2 value reflects the extent to which an exogenous construct can explain other exogenous constructs. The results of PLS R-Square present the amount of variance from the construct described by the model. The R-Square value is a model goodness fit test. The following is a table of relationships between endogenous constructs, which can be seen from Table 5 below

Table 5. R-Square (Mean, STDEV, T-Values, P-Values)

\begin{tabular}{lccccc}
\hline & $\begin{array}{c}\text { Original Sample } \\
(\mathrm{O})\end{array}$ & $\begin{array}{c}\text { Sample } \\
\text { Mean (M) }\end{array}$ & $\begin{array}{c}\text { Standard } \\
\text { Deviation } \\
(\text { STDEV) }\end{array}$ & $\begin{array}{c}\text { T Statistics } \\
(|\mathrm{O} / \mathrm{STDEV}|)\end{array}$ & P Values \\
\hline $\mathrm{KO}$ & 0.797 & 0.810 & 0.058 & 13.801 & 0.000 \\
\hline $\mathrm{KP}$ & 0.690 & 0.712 & 0.070 & 9.842 & 0.000 \\
\hline
\end{tabular}

In the table above can be explained based on the r-square value for Organizational Performance of 0.797, which means that the variability of Organizational Performance can be explained by Organizational Culture Based on Tri Hita Karana, HRM, and Total Quality Management of 79.7\%. Then to construct Employee Performance with a value of r-square 0.690 , which means that employee, performance variability can be explained by Tri Hita Karana's Organizational Culture, HRM, and Total Quality Management of $69 \%$

Significance of Inner Model

The t-table value for the significance level $\alpha=0.05$ and the degree of freedom $(\mathrm{df})=48$ is 2.58 . If $\mathrm{t}$ statistics $>$ from t-table, it can be concluded that the endogenous construct has a significant effect on exogenous constructs. The results of data processing constructs that explain the relationship between exogenous with endogenous constructs can be seen from Table 6 below:

Table 6. Significance of Inner Model

\begin{tabular}{ccccccc}
\hline & $\begin{array}{c}\text { Original } \\
\text { Sample } \\
(\mathbf{O})\end{array}$ & $\begin{array}{c}\text { Sample } \\
\text { Mean } \\
(\mathbf{M})\end{array}$ & $\begin{array}{c}\text { Standard } \\
\text { Deviation } \\
\text { (STDEV) }\end{array}$ & $\begin{array}{c}\text { T Statistics } \\
(\mid \mathbf{O} / \text { STDEV }) \\
>\mathbf{2 , 5 8}\end{array}$ & $\begin{array}{c}\text { P- } \\
\text { Values }\end{array}$ & $\begin{array}{c}\text { Significance } \\
\text { Test }\end{array}$ \\
\hline BO -> KO & -0.017 & -0.024 & 0.078 & 0.220 & 0.826 & Not Significant \\
BO -> KP & 0.830 & 0.834 & 0.048 & 17.353 & 0.000 & Significant \\
MSDM -> & -0.073 & -0.061 & 0.134 & 0.544 & 0.587 & Not Significant \\
KO & & -0.104 & 0.132 & 0.866 & 0.387 & Not Significant \\
MSDM -> & -0.115 & -0.134 & & &
\end{tabular}


KP

\begin{tabular}{lllllll} 
TQM -> KO & 0.947 & 0.940 & 0.115 & 8.232 & 0.000 & Significant \\
\hline TQM -> KP & 0.082 & 0.070 & 0.148 & 0.553 & 0.581 & Not Significant \\
\hline
\end{tabular}

a. The Effect of Organizational Culture towards Organizational Performance

The role of Organizational Culture based on Tri Hita Karana towards Organizational Performance in PDAM Buleleng Regency, has a t-statistic value of 0.220 . With the provisions of t-statistics $>$ from $t$-table $(0.220<2.58)$, the influence of Tri Hita Karana-based Organizational Culture on Organizational Performance is not significant. With a path coefficient of -0.017 (from the original sample column). These results indicate that the indicator of Organizational Culture based on Tri Hita Karana has not been able to show a significant value towards the improvement of organizational performance achievement in the Office of PDAM of Buleleng Regency.

b. The Effect of Organizational Culture towards Employee Performance

The role of Organizational Culture based on Tri Hita Karana towards Employee Performance in PDAM Buleleng Regency, has a t-statistic value of 17,353 . With the provisions of $t$-statistics $>$ from $t$-table $(17,353>2,58)$, the effect of Tri Hita Karana-based Organizational Culture on Employee Performance is significant. With a path coefficient of 0.830 (from the original sample column). These results indicate that the indicator of Organizational Culture based on Tri Hita Karana has been able to provide a good or significant value to the increase in achievement of Employee Performance in the Office of PDAM Buleleng Regency.

c. The Effect of TQM towards Organizational Performance

The role of Total Quality Management towards Organizational Performance at the PDAM Office in Buleleng Regency has a t-statistic value of 8.232 . With the provisions of t-statistics> from t-table $(8,232>$ 2,58), the role of Total Quality Management on Operational Performance is significant. With a path coefficient of 0.947 (from the original sample column). These results indicate that the Total Quality Management Indicator is able to show a significant value on Organizational Performance in the PDAM Office Buleleng Regency.

d. The Effect of TQM towards Employee Performance

The role of Total Quality Management towards Employee Performance at the PDAM Regency Office in Buleleng, has a t-statistic value of 0.5537 . With the provisions of $t$-statistics $>$ from $t$-table $(0.553>2.58)$, the role of Total Quality Management on Operational Performance is not significant. With a path coefficient of 0.197 (from the original sample column). These results indicate that the indicator of Total Quality Management has not been able to show a significant value on Employee Performance in the environment of PDAM Buleleng Regency.

e. The Effect of HRM towards Employee Performance

The effect of HRM towards Employee Performance in PDAM Office Buleleng Regency has a t-statistic value of 0.866 . With the provisions of $t$-statistics $>$ from $t$-table $(0.866<2.58)$, the influence of HRM on Employee Performance is Not Significant. With a path coefficient of -0.115 (from the original sample column). Based on these results, it can be seen that the role of MSDM has not been able to improve the achievement of Employee Performance at the PDAM Office Buleleng Regency.

f. The Effect of HRM on Organizational Performance

The effect of HRM towards Organizational Performance in the Office of PDAM Buleleng Regency has a t-statistic value of 0.544 . With the provisions of t-statistics $>$ from t-table $(0.544<2.58)$, the influence of HRM on Organizational Performance is Not Significant. With a path coefficient of -0,073 (from the original sample column). Based on these results, it can be seen that the role of HRM which includes not being able to improve the achievement of Organizational Performance at the PDAM Office Buleleng Regency.

\section{Conclusion}

Based on the results of the research conducted in PDAM Buleleng Regency, it can be concluded that: The results of a significant relationship were shown in the Organizational Culture variable based on Tri Hita Karana on the performance of the employee and Total Quality Management on Performance of Organization. This shows that Organizational Culture based on Tri Hita Karana of Employee Performance and TQM on Organizational Performance has a significant correlation and the direction of a positive or unidirectional relationship and the results of the analysis show that these two relationships have a positive and significant role, so it can be concluded that organizational culture based on Tri Hita Karana 
and Total Quality Management have their respective significant influence on Employee Performance and Organizational Performance.

Different results were shown in the role of Tri Hita Karana-based Organizational Culture on Organizational Performance, HRM on Organizational Performance, HRM on Employee Performance, and TQM on Employee Performance which indicates that there were insignificant results. This shows that there were several factors that have not been able to show positive and significant values on organizational performance and employee performance at the PDAM Office Buleleng Regency.

\section{Reference}

Alhudri, S., \& Heriyanto, M. (2014). Pengaruh Penerapan Total Quality Management (TQM) Terhadap Kinerja Karyawan Pada PT. PLN (Persero) Ranting Bangkinang. Jurnal Manajemen Dan Kewirausahaan, 12, 1-14.

Arianty, N. (2014). Pengaruh Budaya Organisasi Terhadap Kinerja Pegawai. Bisnis, Jurnal Manajemen \& Bisnis, 14(02), 144-150.

Arikunto, S. (2010). Prosedur penelitian : Suatu Pendekatan Praktik (Edisi Revi). Jakarta: Rineka Cipta.

BPKP. (2015). Laporan Hasil Audit PDAM Kab. Buleleng. Singaraja: PDAM Buleleng.

Christoffel Mintardjo Dan, F. E. W. K. (2016). Pengaruh Praktek-Praktek Manajemen Sumber Daya Manusia terhadap Kinerja Pegawai pada Kantor Pelayanan Kekayaan Negara dan Lelang (KPKNL) Manado. Jurnal EMBA, 4 Nomor. 4, 1229-1248.

Farchan, F. (2017). STRATEGI MSDM SEBUAH CARA MENCIPTAKAN KINERJA ORGANISASI DALAM MENCAPAI KEUNGGULAN BERSAING. Jurnal Pendidikan Dan Studi Islam, 4, 42-52. https://doi.org/10.5281/zenodo.1227139

Ghozali, I. (2008). Structural Equation Modeling Metode Alternatif dengan Partial Least Square (Edisi Kedu). Yogyakarta: Universitas Diponegoro.

Kurniawan, M. (2013). Pengaruh Komitmen Organisasi, Budaya Organisasi dan Kepuasan Kerja Terhadap Kinerja Organisasi Publik (Studi Empiris pada SKPD Pemerintah Kabupaten Kerinci). Skripsi FE Universitas Negeri Padang. https://doi.org/10.1073/pnas.0703993104

Laili, M. D. N. (2016). Pengaruh Total Quality Management Terhadap Kinerja Karyawan Pada Pt . Harlis. EJournal Ilmu Administrasi Bisnis, Vol 4(No. 4), 1140-1150.

Mangkunegara, A. A. A. P. (2008). Manajemen Sumber daya Manusia. Bandung: Remaja Rosdakarya.

Musran Munizu. (2010). Pengaruh Faktor-Faktor Eksternal dan Internal Terhadap Kinerja Usaha Mikro dan Kecil (UMK) di Sulawesi Selatan. Jurnal Manajemen Dan Kewirausahaan, 12(1), pp.33-41. https://doi.org/10.9744/jmk.12.1.pp. 33-41

Pratama, Y. (2012). Pengaruh Budaya Organisasi terhadap Kinerja Pegawai pada Kantor Kecamatan Nanggung Kabupaten Bogor. Universitas Indonesia.

Sagiv, L., \& Schwartz, S. H. (2007). Cultural values in organisations: insights for Europe. European J. of International Management, 1(3), 176. https://doi.org/10.1504/EJIM.2007.014692

Schwartz, S. H. (2007). Cultural values in organisations : insights for Europe Lilach Sagiv, 1(3), 176-190.

Sugiyono. (2012). Statistik Untuk Penelitian. Bandung: Alfabeta.

Ustriyana, R. K. D. D. I. N. G. (n.d.). Keberlanjutan Nilai-Nilai Tri Hita Karana (THK) pada Sistem Subak di Kawasan Wisata dan Kawasan Agraris Kabupaten Gianyar, 1-19. 
Wayan Windia, R. K. D. (2011). Analisis Bisnis berlandaskan Tri Hita Karana. Denpasar: Udayana University Press.

Winata, I. G. K. A., Windia, W., \& Suartana, I. W. (2015). Membangun Strategi Operasi melalui Budaya Organisasi Berbasis Tri Hita Karana untuk Mencapai Keunggulan Bersaing Berkelanjutan : Kasus pada Lembaga Perkreditan Desa di Kabupaten Buleleng Absrtact Pendahuluan Kajian Pustaka. Jurnal Manajemen Agribisnis, 3(2), 81-92. 